\title{
Unity Vs. Uniformity: The InfLUenCE of Ziya Gökalp and John Dewey on the Education System of THE RepUblic of TURKeY
}

\author{
Raşit Çelik
}

\section{ABSTRACT}

Creating a democratic nation-state and sustaining its progress was seen by the founders of the Republic of Turkey as necessary to achieving the goal of becoming a distinguished member among developed civilizations. The founders conceived of education as a main instrument in disseminating this new ideology and ensuring the emergence of a culture of democracy in Turkish society. Accordingly, establishing a new education system was a primary consideration during the early years of the Republic. Scholars, looking at the issue from diverse perspectives, have routinely revealed the influence of John Dewey's report on Turkish education and discussed how his recommendations were applied by Turkish officials. Unlike previous studies, however, this article aims to analyze the influence of both Dewey and Ziya Gökalp on Turkish education and from both ideological and practical perspectives, despite their dissimilar ideas on some fundamental issues.

\section{INTRODUCTION}

Once the Ottoman Empire collapsed, a new Turkish state was established after a struggle for national freedom. The founder of the Turkish Republic, Mustafa Kemal Atatürk, ${ }^{1}$ aimed to develop a western-like democratic state for the people of the remaining Empire, even though he could have become the next sultan. All stages necessary for the emergence of a new state had already been fulfilled before the collapse of the Ottoman Empire, and the establishment of the Turkish Republic was the final element within the transformation process of the Ottoman state. ${ }^{2}$ Atatürk, as the successor of the Young Turks who gained political power through the constitutional movement in 1908, abolished the monarchy and established a secular republic, a western-like democracy. ${ }^{3}$ Yet, the new state, the Republic of Turkey, encountered some profound problems with respect to its desire to develop a new social and political structure in order to establish a full-fledged democracy. It was not an easy task for the leaders of the Republic, especially considering the 


\section{RAŞIT ÇELIK}

fact that the idea of democracy was a completely new concept for people who had been under the rule of an empire, an absolute power and authority, for centuries. This end demanded a whole transition: not only a change in political and economic structures but also a cultural transformation that was highly dependent upon the education of the masses. Within this context, the Republic conceived of education as an essential instrument in order to re-shape the social order, to inform citizens about democracy, and to disseminate the new ideology.

This study examines the essential perspective of Kemalism ${ }^{4}$ on concepts, such as nation, culture, and education, while elucidating the ideas of some influential figures in Atatürk's thoughts on such notions. In particular, two prominent thinkers, Ziya Gökalp and John Dewey, had a significant impact on the official ideology and education system of the Turkish Republic. Gökalp's Turkism and Dewey's ideas on the education system of Turkey are the focal points throughout this study. While Gökalp was a main source of the Kemalist nation-state, Dewey's thoughts about Turkish education provided practical examples of educational reform in order for Kemalism to develop a desired society. However, official authorities did not consider Dewey's concerns on some important issues, such as centralization and uniformity. Rather, the leaders during the early republican period adopted Dewey's suggestions in a different way from his actual intentions. Some important educational reforms and organizations indicate that the Turkish state during the early period found the theoretical aspect of Turkish education in Gökalp's Turkism and some practical solutions in Dewey's ideas on education. In short, I argue that Kemalism modified Dewey's suggestions within the official understanding of nation-state based on Gökalp's Turkism. In this sense, I also argue that Gökalp framed ideas while Dewey provided ways and means, although the two thinkers held different conceptions of the individual and viewed the role of emotions in educating members of a society from different perspectives.

\section{IDEOlOGICAl RoOts of A NATION-STATE}

Religious toleration was an essential characteristic of the Ottoman state. ${ }^{5}$ In a broader sense, toleration was one of the distinguishing features of the Ottoman community and a governing principle embraced by the Ottoman rulers. Despite the fact that the Ottoman state was an empire and that Islam was the foundation of the state, Ottoman rulers never tried to impose a single culture based on one religion or language. Ottomans developed a unique social order called the millet system to maintain the social unity of the different communities of the Empire based upon the ideas of autonomy and equality. This system can be traced back to the conquest of Constantinople. Mehmet II granted the patriarch and Greek Church full religious and civil authority over its own Orthodox millet despite being dependent on the support of the Ottoman sultan. ${ }^{6}$ This autonomy, in time, was extended in the same way to the other millets, such as Armenians and Jews. All millets of the Empire 
were subject to the same political constraints but could form autonomous institutions, such as education and court systems. The unity of the Empire was dependent upon the equality of its subjects regardless of their differences in culture or belief.

However, during the late Ottoman period, the impact of the French Revolution in Ottoman society was obvious. ${ }^{7}$ Although different millets had enjoyed religious freedom and autonomy, they began demanding full autonomy and complete social justice. For example, the Armenian millet of the Ottoman society sought more autonomy in the Congress of Berlin in 1878. Eventually, the Ottoman Empire was forced to agree to making reforms in the Armenian territories of the state. ${ }^{8}$ Similarly, not only Armenians but also other millets, such as Serbs, Greeks, and Arabs were demanding more autonomy. Under the pressure of the existing social problems, along with political and economic instabilities, the Ottoman Empire or the sick man of Europe was less likely to survive its territorial integrity.

During the last period of the Ottoman Empire, Ottoman thinkers developed various ideologies in order to secure and strengthen the integrity of people under the reign of the Empire. Although such attempts as Pan-Islamism, Ottomanism, Pan-Turkism, and Turkism variously contributed to this end, the Ottoman Empire was unable to survive after World War I. Indeed, after being defeated in World War I, Ottoman territories were partitioned by the victorious countries. Soon after this, however, a Turkish independence movement was generated and led by Atatürk. From May 19, 1919, to the proclamation of the Republic of Turkey on October 29, 1923, and eventually to the Treaty of Lausanne on July 24, 1924, the people of the remaining lands (Anatolia) of the Ottoman Empire struggled against the occupying states to regain their national freedom.

A new democratic regime replaced the previous ideology. After being ruled by Ottoman emperors for centuries, the citizens of the Turkish Republic needed to understand and embrace a new worldview. The ideology of the newly established Turkish Republic required people's active participation in and positive contribution to the social and political life of the society at every level. Yet, a vital problem for officials was to ensure the survival of the new Republic. Territorial integrity of the remaining lands of the Republic, which were inherited from the Ottoman Empire, was very difficult to attain. Thus, the achievement of socio-political integration and stability was still a challenge for the newly founded Turkish Republic.

Earlier movements to bolster integrity were not completely abandoned after the collapse of the Ottoman Empire and the establishment of the Turkish Republic. Indeed, the official ideology of the Republic of Turkey embraced most aspects of Turkism and Pan-Turkism in order to ensure the stability of the Republic. ${ }^{9}$ The Empire and the new Republic focused on different perspectives to this movements in order to deal with the stability problem. While Turkism and Pan-Turkism were among the ideologies discussed during the late Ottoman Empire, the Ottoman ruling elite did not acknowledge them. Ottomanism, as a cosmopolitan perspective 


\section{Rașit ÇELIK}

in which each different nationality was seen as an equal subject of the Empire, was the main ideology embraced by Ottoman officials. ${ }^{10}$ Nationalism based on Turkism, in contrast, was later adopted by the Republic. Atatürk constructed his and, thus, the state's national ideals based primarily upon Gökalp's perspective on Turkness, the nation, and education.

\section{GÖKALP'S INFLUENCE ON KEMALISM}

Gökalp played a major role in the development of a national consciousness with a considerable influence on Atatürk's ideas and in constituting the complete Kemalist ideology. ${ }^{11}$ Gökalp's notion of Turkism significantly influenced the development of the new Republic's official ideology, based on Turkish nationalism, and became a fundamental part of Kemalism. ${ }^{12}$ Akural explains that even though influential Kemalists were not disciples of Gökalp, it is impossible to think of their work and approach without Gökalp. ${ }^{13}$

Gökalp's influence on the Kemalist perspective can clearly be seen in the program of the Republican People's Party (RPP). ${ }^{14}$ Gökalp's understanding of nationalism, for example, appears in one of the most important documents of Kemalism, the party regulation of RPP adopted in 1927. Article five of that document "recognizes the unity of language, sentiments, and ideas as the strongest bonds of the national solidarity and attaches a special priority to the development of the Turkish language and Turkish culture."15 Gökalp's nationalistic positions in various areas, such as law, economy, and religion, influenced the party platform of the RPP in 1935. ${ }^{16}$ In Kili's words, "during the RPP Congress held in 1927, 1931, and especially 1935, a good deal of work was done on the development of Atatürkism ${ }^{17}$ as a system of thought."18 The 1935 congress of the RPP was especially important, since Kemalism was announced and systematized. Kemalism had four cardinal principles of Fatherland, Nation, Constitution of the State, and Public Rights; as well as essential characteristics, or six principles, which are Republicanism, Nationalism, Populism, Etatism, Laicism, and Reformism, which were later adopted in article two of the Constitution. ${ }^{19}$ Additionally, the RPP's program of 1935 considered the preservation of the special character and entirely independent identity of the Turkish social community essential. ${ }^{20}$ These examples reveal the way Gökalp's Turkism was stated concisely and officially within the Kemalist understanding.

Gökalp's understanding of cultural nationalism takes its roots from historical sources of old Turkish culture. Kemalist understanding of cultural nationalism advocates the adoption of European values for the revival of the Turkish nation. In other words, although Gökalp's Turkism is more related to Pan-Turkism, it was adopted by Kemalism from a more Turkish perspective, which is Turkism based on Turks of Anatolia. Yet, these two perspectives meet at a common point in that the goal of Turkish nationalism is to preserve Turkish history and allow it to flourish within a modern Turkish culture. Some reforms implemented by Atatürk show 
practical applications to achieve this end, such as the alphabet reform in 1928; the foundation of the Turkish Historical Society in 1931, which is a research society examining the history of Turkey, Turks, and Turkish culture; and the establishment of the Turkish Language Association in 1932, which is responsible for academic studies of the family of Turkic languages. The Turkish language is a significant byproduct of Turkism introduced by the administration of Atatürk. Moreover, the Turkish Historical Society and Turkish Language Association were used for the purpose of disseminating the new political ideology and the basic principles of Kemalism, especially nationalism and laicism. ${ }^{21}$ In this sense, while being conscious of the historical origins of Turkish culture and language, Kemalism advocated directing Turkish culture towards a western-like modern democracy based upon Turkish cultural traits.

However, this social change targeted by Atatürk demanded a right kind of citizenship without which democracy would not survive in the new Republic with the idea of a nation-state. The social revolution projected by Atatürk was highly dependent upon the education of the members of the Republic. Since, for Gökalp, the ultimate aim of education is to create national individuals, ${ }^{22}$ his notion of education influenced Atatürk's understanding of education and of the role of schools as agencies of social control and diffusers of culture. ${ }^{23}$

Gökalp put a significant emphasis on the vital role of education in order to develop a society that internalizes and works for the culture, language, and ideals of the Turkish nation. Even though Gökalp acknowledged that there were various groups of people in Turkish society whose ancestors came from different places in the past, he also stressed that if they are educated as Turks and habituated to work for Turkish ideals, then there is no need to exclude them from others who believe that they are Turks. ${ }^{24}$ As Akural shows with a study in which Kurdish tribes were classified by Gökalp as "Kurdified Turks," ${ }^{25}$ Gökalp's method ignores and denies the other's culture while highlighting old Turkish culture of Turks of Anatolia. ${ }^{26}$ In addition, the main purpose of this study, as mentioned by Riza Nur, who was a founding member of the Grand National Assembly of Turkey and later Minister of Education in 1920, was to prove from a scientific standpoint to Kurdish people that they are Turks in origin. ${ }^{27}$ Moreover, since education in Gökalp's approach plays a principal role in establishing cultural uniformity, it is not surprising that that study was sponsored by the Ministry of National Education. This example indicates how the official authority at the time aimed to secure and rationalize the uniformity of Turkish culture based on Gökalp’s Turkism.

The Turkish Republic systematized its understanding of Turkism, nation, and the role of education based primarily upon Gökalp's conception of Turkism. Yet, Kemalist nationalism, which is based on Turkish citizenship, is not to be regarded as a racial approach. Similar to Gökalp's thinking, the Kemalist notion of a nation is about Turkish ideals only. In Kili's words, 


\section{RAŞIT ÇELIK}

accounting to Kemalist ideology, Turkishness was not necessarily determined by one's race or religion but by the degree to which a person associates himself with the ideas, ideals, and goals of the Turkish nation and by determination to protect all that had been won as a result of great hardships, and also by commitment to Turkish modernization. ${ }^{28}$

Atatürk developed his nationalist perspective on a theoretical basis. However, this theory needed to be put into practice in order to accomplish the ideals of the new Republic. Developing a new notion of the Turkish nation, introducing democracy to the citizens, and organizing a democratic way of life both in the social and political arena were immediate problems of the Republic during its early years. As mentioned above, education was perceived as one of the most relevant instruments for addressing these. Education in the Kemalist perspective, therefore, was a crucial instrument for developing and safeguarding the continuity of the integrity of the Turkish Republic with its territory and citizens. Although Atatürk had already found a theoretical basis for the educational ideals of the Republic, he was still in need of practical solutions in order to develop the desired education system.

Dewey appears in the history of Turkey in this phase with his education proposal for the newly established Republic. However, some aspects of education that were influenced by Dewey's recommendations signify a conceptual gap between Dewey's ideas and the ideology of the state. As discussed by Dorn and Santoro, education policies reflected different ends for Dewey and Turkish officials, since the former stood for democratic localism while the latter aspired to a democratic nation-state for the future of the newly established Republic. ${ }^{29}$ Since education was perceived as the main instrument to organize and form citizens, society, and culture in general, centralization and uniformity in education and in the entire political and social order had the highest priority for Turkish leaders. As previously discussed, Gökalp established the principles of a nation-state and provided some fundamental ideas for the new Turkish state's ideology. With this in mind, one may evaluate Dewey's education proposal and its impact on the Turkish education system from an alternative perspective. Before looking at Dewey's proposal, however, a discussion of some essential differences between Gökalp's and Dewey's ideas on society and education will be beneficial.

\section{GÖKALP ANd Dewey On SOCIETY AND EduCATION}

Gökalp developed his notion of Turkness by highlighting cultural and national traits and emphasizing the role of education in developing a nation. He first discussed what Turkism is not, by showing inadequate explanations from other emerging notions of nationhood, especially during the late Ottoman period. He then clarified his understanding of nationhood and its relation to education. ${ }^{30}$ According to Gökalp, Turkism is a theory based neither on race nor on ethnicity. There is no 
necessary relation between race and nationality that makes social and nationalistic characteristics dependent on race. Similarly, there is no ethnic purity that can support any nationalistic perspective since, according to him, no society, even in pre-historic times, was ethnically pure, even though ancient societies claimed that they were pure ethnic groups. He further argued that nationalism could not be explained by any geographic area in which a group of people lived and shared common traits since there are various groups that hold the same culture and language but live in different geographical locations around the world. Therefore, according to him, Turkism is not a geographic concept.

Gökalp stressed that nationalism cannot be reduced to a single component of pluralistic societies, such as Ottoman society. That is, considering all subjects of a pluralistic society under a single nation is a misidentification, since each nation holds distinct cultures. In addition, he stated that a nation is different from what is called an Ummet, which refers to a group of people that hold the same religious doctrine, whereas a nation is a group of people that possess a common language and culture. Thus, he clearly distinguished religion from nation. Lastly, he argued that the individualistic perspective, which defines a nation as a group of people consisting of individuals who consider themselves members, is not tenable. Nation, according to Gökalp, is not something that can be changed freely, such as by joining a different political party. Instead, he argued, there is no such freedom of belonging to a nation. He asserted that an individual receives a life-long education from the society in which he or she lives, through which his or her sentiments are formed in favor of his or her society. Therefore, for Gökalp, an individual may come to belong to the society in which he or she lives with a strong emotional bond acquired by life-long education. Education, thus, appears in his theory as a crucial element in order to develop a robust national solidarity.

After clarifying that Turkism is not based on any ethnic-centered, geographic, Ottomanist, Pan-Islamist, or individualist entity, Gökalp explicated his notion of nation by placing a crucial emphasis on the role of education. In his words, "a nation is not a racial or ethnic or geographic or political or volitional group but one composed of individuals who share a common language, religion, morality and aesthetics, that is to say, who have received the same education." ${ }^{31}$ This education, which develops a sentimental allegiance in individuals to their nation, cannot, according to him, be erased from the souls of individuals, and thus they are internally forced to remain within the society to which they belong. Moreover, Gökalp argued that genealogy is not an essential element of nationality. He stated that, "for the human being, spirituality takes precedence over materiality; therefore, one's pedigree is not to be sought in nationality but only in national education and ideals." ${ }^{2}$ With this explanation, he highlighted the importance of an education that constructs strong sentiments and ideals within individuals towards their society and regardless of their biological origins. According to him, an individual can work 


\section{Rașit ÇELIK}

and even sacrifice his or her life for the sake of his or her own society "only for the ideal of nation in which he/she has been educated." ${ }^{33} \mathrm{He}$ argued that no one comes into the world with any linguistic, religious, moral, aesthetic, political, legal, or economic conscience, as these are values and characteristics that are not carried by genetic heritage, but only through education. ${ }^{34}$

Although there may be similarities between Gökalp's and Dewey's notions of society and educational aims, the gap between the two perspectives is ultimately deep. A close understanding may reveal that these two accounts profoundly differ from each other in the way they conceptualize certain ideas, such as unity, ideals, and aims. Unity, for Dewey, indicates a common allegiance and effort that bring different ends pursued by various groups together under the power of common ideals, which in effect holds them as one. ${ }^{35}$ In other words, unity in Dewey's account appears as the unity of the ideals held by members of society. He further argues that once individuals are accustomed to the ideals and actual conditions as a unit, as human psychology supports, such unity becomes instilled as emotion, which then becomes difficult to dissolve and remains an authority over these individuals. ${ }^{36}$ That is to say, a combination of ideal ends and actual conditions, which are promoted by emotions, lead the individual's actions and interactions with others since, as Dewey argues, aims and ideals do not merely exist in mind but rather in character, personality, and action. ${ }^{37}$ As may be seen, this line of argument seems akin to Gökalp's, since it argues that a strong sentimental allegiance, developed within individuals through education, ensures that members are internally forced to work for the ideals of the society to which they belong.

However, Dewey, in contrast to Gökalp, argues that emotions that are already deposited in individuals hinder experience and growth. Dewey values knowledge that comes from direct experience, over that which is borrowed from what is currently available within the surrounding culture, without criticism, since, in light of the scientific method that ascertains facts and truths, he criticizes any dogma and doctrine that advocates definite beliefs that are learned and taught as truth. ${ }^{38}$ From this perspective, it may be argued that Gökalp establishes an ideal theory of a nation-state composed of national individuals who are imbued with national sentiments through a state-sponsored centralized education, and who habitually tend to work for the ideals of the state. Dewey, in contrast, argues that

we cannot set up, out of our minds, something we regard as an ideal society. We must base our conception upon societies which actually exist, in order to have any assurance that our ideal is a practicable one. ${ }^{39}$

Therefore, it may be asserted that, for Dewey, as opposed to Gökalp, a society is to establish its own ideals in accordance with its own experience and actual conditions, as a unity of various ends and ideals held by different groups. For this reason, the democratization project pursued by the Republic appears at bottom 
incompatible with the ideas provided by Dewey. He highlights two characteristics of a democratically constituted society: (1) social control relies upon the recognition of mutual interests, supported by various shared interests within society, and (2) there must be free interactions among social groups and continuous change in social habits, that is, continuous readjustments that enable the society to comply with new situations derived from social interactions. ${ }^{40}$ In a democratic society, therefore, ideals originate and evolve in accordance with the experiences of society itself and promote growth. Ideals in such society do not refer to a set of ideals that are externally established and instilled into members of this society. Thus, neither of the two characteristics of a democratic society seem to be evident in the Republic in the early period. Rather, social ideals were framed by the state itself as an outcome of vested interests with power, which in fact would be criticized by Dewey, as he regarded such a situation as remaining on the side of the status quo and preventing experience and growth. ${ }^{41}$

Moreover, Dewey argued that an educational purpose that aims for social efficiency must cultivate power in individuals in order to enable them to join freely and fully in shared activities with others, which in effect ensures the characteristics of a democratically constituted society. ${ }^{42}$ This reveals another conflict with Gökalp's overall ideas, since, as discussed above, he does not conceive of members of society as being free to participate in developing social ideals through their own experiences and interactions with others, but as members that are subjects to be endowed with shared ideals. Since democratic society rejects the idea of external authority, ideals are to be voluntarily developed, which is possible only through education, as Dewey argues. ${ }^{43}$ In other words, Dewey believes, in accordance with his democratic ideals, that educational aims are not to be determined by external dictates. Instead, they are to arise from experience and lead to growth, which indicates that educational aims are not to be attached to ends outside of the educative process. ${ }^{44}$

In short, Gökalp tried to extend the definition of Turkness from an ethnic account to a much broader one. That is to say, those who have been educated in the Turkish language, culture, and ideals, and who have internalized these national traits are to be recognized as Turks. Gökalp ultimately wanted to provide a logical and acceptable definition of a Turk by including others who are not ethnically Turks. He simply aimed to secure the territorial and cultural wholeness of a pluralistic society by fitting all components of such a society into the definition of Turkness regardless of people's racial or ethnic identities. In fact, this approach was embraced by Atatürk as a constituent element of the ideology of the Republic and a moral principle through which citizens could develop strong sentiments towards the indivisible nation-state. The problem of social unity, then, found a theoretical response with Gökalp's ideas. This response, in effect, aimed to integrate different components of a pluralistic society under a single identity, which may be considered a uniformity rather than a unity. Educating national individuals for the realization 


\section{Rașit ÇELIK}

of this aim appeared to be vital. No doubt, Dewey's notions of democracy, society, and education were essentially incompatible with this perspective. Thus, one can see why Dewey's educational proposal was interpreted differently and why some educational implications which arose from his report were put in practice in order to accomplish different ends from those Dewey actually embraced.

\section{Dewey And Turkish Education}

\section{Dewey's Report and Recommendation}

Dewey was known as the genius of progressive education. The aims of progressivism in general, and Dewey's ideas about educating citizens, reshaping the social order based on democratic principles, and creating a democratic culture, attracted the founding fathers' attention even before the establishment of the Turkish Republic. In fact, starting from the first decade of the twentieth century, Turkish scholars learned about Dewey's educational philosophy, first through the works of some European thinkers. ${ }^{45}$ Later, some of Dewey's works were translated into Turkish prior to his visit. Moreover, the origin of Atatürk's educational perspective was already based upon Dewey's philosophy, through the works of some influential Turkish educators during the 1920s, and before Dewey's invitation to visit. ${ }^{46}$ All of these factors indicate that not only Turkish educators but also the founders of the new Republic were enthusiastic about Dewey's educational ideas. Still, his ideas gained more attention among Turkish educators after his visit to Turkey. As Wilson stated in 1928, "every Turkish educator knows something about John Dewey" and "many of them can discuss intelligently his educational philosophy." ${ }^{37}$

Dewey was officially invited to Turkey in 1923 through a letter from the Minister of National Education of the Turkish Republic and by order of Atatürk. Dewey accepted the invitation and visited Turkey in the summer of 1924, staying from July 19 to September 18 . The main purpose of his visit to Turkey was to propose a modern educational system for the newly established Turkish Republic. It was presupposed that Dewey's educational report might help develop new generations with a new notion of Turkish culture in accordance with the principles of democracy.

Dewey prepared the first part of his report before leaving Turkey. In his Preliminary Report, Dewey made suggestions regarding the most urgent needs of Turkish education, such as preparing an educational budget and allocations of funds. He wrote his main report in the United States, in which he made specific recommendations for establishing and improving an educational plan, organization of the Ministry of Public Instruction, training and treatment of teachers, and system, discipline, health and hygiene in schools. ${ }^{48}$

Dewey started his report by highlighting the importance of the role and aims of schools in Turkey. Defining and determining the aims and purposes of the schools, according to Dewey, were the most prominent educational problems. He 
put a considerable emphasis upon the means and ends of Turkish education. Dewey mentioned that becoming clear on the objectives of education not only might prevent Turkish schools from needless changes, but also might reveal the steps that should be taken in education. ${ }^{49}$

Dewey's report confirms that he clearly comprehended the ideals of the founders of Turkish Republic. His report summarized the primary objective of Atatürk's ideas as "the main end to be secured by the educational system of Turkey, it is the development of Turkey as a vital, free, independent, and lay republic in full membership in the circle of civilized states." ${ }^{50}$ Moreover, Dewey listed three points regarding how to reach this end.

Schools must (1) form proper political habits and ideas; (2) foster the various forms of economic and commercial skill and ability; and (3) develop the traits and dispositions of character, intellectual and moral, which fit men and women for self-government, economic self-support and industrial progress; namely, initiative and inventiveness, independence of judgment, ability to think scientifically and to cooperate for common purposes socially. ${ }^{51}$

Dewey's ideas, as stated in his report, are unquestionably in alignment with the ultimate political and educational aims of the Republic. Since Dewey clearly emphasized the vital role of education alongside the primary objective of the new Republic, he became the most appreciated thinker by Turkish educators. To this day, Dewey is still the most influential non-Turkish thinker in the development of education in the history of the Turkish Republic.

\section{The Influence of the Report on the Development of Turkish Education}

What makes Dewey the most important foreign educator to engage in the educational problems of the Turkish Republic is the fact that he also contributed to the reformation process of Turkish society. One of the main characteristics of Turkish modernization is that it was both a state-centered and an education project. ${ }^{52}$ As mentioned above, Dewey correctly comprehended the ultimate aim of the Kemalist perspective for the future of the Republic and developed his report in accordance with it. In the early period of the Republic, different educational reforms applied to Turkish education were in accordance with Dewey's ideas and recommendations. For example, the Turkish Board of Education was established in 1926 in light of Dewey's report. Also, he had a significant role in the modernization process of social studies curriculum as well as in the development of the teacher education system in Turkey. ${ }^{53}$

However, the educational ends targeted by the state were different from what Dewey had suggested. The essential characteristics of the curriculum in Turkey were national concerns, modernization, and secularism. The notion of citizenship, especially during the early years of the Republic, was a focal concern in the 
curriculum. Such characteristics, and the focus on citizenship, served as part of a state-centered modernization project based upon such traits as democracy, secularism, and the nation-state. ${ }^{54}$ The 1926 curriculum, which was developed under the influence of Dewey's report, aimed at forming good citizens during primary school who would contribute to their society, while leaving the meaning of being a good citizen and appropriate ways to be active contributors unclear. ${ }^{55}$ Yet, starting with the curriculum of 1930, educational objectives with respect to citizenship became clearer. For example, developing good citizens who are committed to the Republic and the Turkish nation was indicated as an educational aim in 1930, and in the following years it took on a more national character emphasizing the education of citizens who respect and believe that the Turkish Republic, with its indivisible integrity, is a national, democratic, secular, and social state. ${ }^{56}$

In fact, these characteristics of the Turkish education system were framed a few months prior to Dewey's visit to Turkey. The Law of Unification of Education, enacted on March 3, 1924, created a highly centralized education system under the control of the Ministry of Education, which also outlined the nationalistic character of education in Turkey. However, Dewey was aware of some potential dangers for the Turkish Republic, since he already had experience in understanding how education should lead a revolutionary and developing country. ${ }^{57}$ Dewey emphasized, concerning the new Republic, that "in a country which has not had a general system of public education ... the Ministry of Education must take the lead. ${ }^{58}$ At the same time, he highlighted the danger of an overly centralized educational system while taking the educational lead. Local differences and responsibilities taken on by local communities are important components of Dewey's conception of democratic education. According to him,

there is danger that too much and too highly centralized activity on the part of the Ministry will stifle local interest and initiative, prevent local communities taking the responsibilities which they should take; and produce too uniform a system of education not flexibly adapted to the varying needs of different localities, urban, rural, maritime, and to different types of rural communities, different environments and different industries. ${ }^{59}$

Another important concern mentioned by Dewey in his report addresses the difference between unity and uniformity. Although Dewey is criticized for not understanding the meaning of the Turkish revolution, along with his inability to grasp the required reforms for the Turkish Republic and urgent problems of Turkish education, ${ }^{60}$ he was well aware of the Turkish Republic's need for integrity both in the social and political spheres. However, Dewey placed emphasis on the difference between unity and uniformity. He stated that,

While Turkey needs unity in its educational system, it must be remembered that there is a great difference between unity and uniformity, and that a 
mechanical system of uniformity may be harmful to real unity. The central Ministry should stand for unity, but against uniformity and in favor of diversity. Only by diversification of materials can schools be adapted to local conditions and needs and the interest of different localities be enlisted. Unity is primarily an intellectual matter, rather than an administrative and clerical one. It is to be attained by so equipping and staffing the central Ministry of Public Instruction that it will be the inspiration and leader, rather than dictator of education in Turkey. ${ }^{61}$

These concerns raised by Dewey were only partially taken into account by Turkish authorities. In the early period of the Turkish Republic, rural and urban schools differed in general curriculum content. The central Ministry of National Education created different curricula for urban and rural areas. However, only a single type of curriculum was provided for all rural areas, with another monotype for all urban areas. The differences between rural and urban areas in economic conditions and activities were the only considerations made by the Ministry. One of the most significant differences between the two curricula was that no agriculture was taught in urban areas, while six hours of agriculture per week was taught during the five-year elementary school course in rural areas. ${ }^{62}$ Obviously, such a difference would not fully reflect Dewey's recommendations. As mentioned in the above quotation, Dewey suggested not only different education systems for rural, urban, or maritime areas, but also different educations for different types of rural and urban areas. Although it seems, at first, that differences in localities were considered by the state, the authorities applied Dewey's suggestions in a way in that ensured the domination of the central power over different localities.

One important point that appears as a misunderstanding of Dewey's recommendations deals with different models of teachers and related teacher training schools. Primary teachers education schools and village teacher education schools were established in order to satisfy the demand for teachers in the country, but after the education law passed in 1926 influenced by Dewey's report. ${ }^{63}$ In fact, Dewey placed significant importance on teachers' roles in providing a proper education for society. In his report, he highlights the need for improving teachers' working conditions in Turkey in order for them to be fully committed to accomplishing the educational ends for the development of Turkish education and society. After his report appeared, teachers were promoted through substantial increases in their salaries and housing opportunities, for example. ${ }^{64}$ What is in conflict with Dewey's recommendations and general outlook, however, is the fact that, rather than providing help for students, Turkish teachers were part of a centralized education system in a way that put them at the center of the learning process as the main sources of knowledge, which served to inculcate the official ideology into students. ${ }^{65}$

Moreover, a look at some educational institutions that were significantly influential in promoting uniformity may help in revealing the ideological background 
of the educational policy and implementations applied during the early republican era, which also may provide insight into why educational policies and practices that were influenced by Dewey's report were not in fact Deweyan. The Turkish education system has been a part of the state's modernization project based upon the idea of developing a western-like democratic nation-state. Such reformist organizations as Turkish Hearths, People's Houses, and Village Institutes significantly influenced the development and modernization of Turkish society, while serving important educational functions. Turkish Hearths was founded in the Second Constitutional Period in 1908 and continued to spread the ideals of Turkish nationalism after the establishment of the Turkish Republic. ${ }^{66}$ Subsequent important educational institutions, The People's Houses, founded in 1932, replaced the Turkish Hearths. The People's Houses were directly controlled by the RPP and aimed to disseminate the ideology of Turkish nationalism and Kemalism. ${ }^{67}$ While the Hearths and Houses targeted adults, the Village Institutes, founded in 1940, focused on younger generations in order to educate and expand the ideals of Kemalism, especially among peasant youth. Those peasant youth, after being educated for five years in the Institutes, returned to their own villages as teachers and continued spreading educational opportunities and the ideals of the Turkish Republic. Dewey's ideas played an influential role in the organization of the Houses and the Institutions. Indeed, the establishment of the Institutions is seen as the most visible impact Dewey made on the Turkish education system. ${ }^{68}$ His influence is recognizable in the forming the Institutions from construction to educational administration and curriculum. Every villager participated in constructing the Institutes and

the students [were] involved in every step of work activities, from the establishment of goals to evaluation. The task of the teacher was to assist the students with her advice. Saturday meetings were an important part of the institute life. Every Saturday, the members of the institute gathered to evaluate the week and solve the problems and crises. ${ }^{69}$

This quotation exemplifies, to some extent, that what Dewey actually suggested was applied into practice. In this way, as Dewey suggested in his report, the school was brought into connection with the community life, while at the same time students' learning and intellectual habits was practically formed instead of remaining theoretically idle and useless. ${ }^{70}$ It signifies also that such educational institution combined Gökalp's belief in the power of a state-sponsored central education system in shaping society in an emerging democracy with Dewey's vision of formal education as an essential democratic institution. In other words, while Dewey played an important role in organizing such educational institutions, political authorities regarded him as a guide in developing a concrete set of instruments for disseminating Turkish nationalism and Kemalism through Turkish national education. Although Dewey aimed for a specific notion of society and a democratic educational perspective, his 
suggestions were put into practice by the authorities in order to arrive at a different end. This end was the uniformity of the state with respect to its history, language, education, and all other cultural traits in both social and political spheres, which was to be strengthened by sentimental allegiance.

\section{CONCLUSION}

Inherited social and political problems of the Ottoman Empire did not allow the leaders of the Republic to overcome the long-lasting fear of separation. The integrity of the people of the society was already a vital problem for the leaders even before the establishment of the Republic. The Kemalist Republic was established upon the idea of the indivisible integrity of the people of the Turkish Republic. In this manner, demands of different cultural groups "were suppressed in the name of safeguarding the indivisible integrity of the state with its territory and nation." Thus, ensuring the survival of the newly born Turkish Republic had the highest priority while the modernization of Turkish society was the ultimate goal.

Gökalp focused on the question of nationalism and education. The Turkish Republic could internalize western education and civilization. Yet, for him, the state needed to remain tied to the roots of its national culture. On the one hand, Gökalp significantly influenced Atatürk and, thus, Kemalism and the regulation of the RPP. His notion of Turkism and efforts to construct an understanding of the Turkish nation, which comprised every single individual regardless of his or her ethnic, religious, or cultural background and which attempted to create a single national culture with a single language, dominated Kemalism and determined social and political reforms, especially in the early period of the Turkish Republic. On the other hand, as the most influential foreign educator in the history of Turkey, Dewey, his idea of progressive education and his report, influenced educational reforms and regulations since he made substantial recommendations for the advancement and modernization of Turkish society. However, his considerations about such topics as centralization, locality, unity, and uniformity were modified in accordance with the current ideological atmosphere of the time.

In contrast with the educational policies implemented by the Turkish state under the influence of Dewey's ideas, the school is to involve students in educational settings from genuine democratic life, instead of attempting to prepare them for their future lives by providing a body of information for future use. The correct way to transmit those values to children, for Dewey, requires providing appropriate educational settings where students can experience the values of their society in order to make such values real and significant for their own lives. ${ }^{72}$ Dewey's understanding of democracy as a way of life promotes and provides an ideal way of living in a democratic society for concrete individuals. In his words, "a democracy is more than a form of government; it is primarily a mode of associated living, of conjoint communicated experience." ${ }^{\prime 3}$ The school, given this notion of associated 


\section{Rașit ÇELIK}

life, rather than being isolated from the life outside the school, is to be the place where students experience democratic life itself. Social progress, therefore, depends on students' firsthand experiences in the school. How and what they experience in the school is, therefore, significantly related to the aims and purposes of education.

As previously discussed, however, one of the main aims of education was to serve the state-centered project in Turkish society, which aimed at westernization and democratization while developing a nation-state based on Turkish culture. In this sense, some educational institutions and educational developments in, for example, curriculum and the teacher education system, which were influenced by Dewey's ideas, were used to disseminate the Kemalist ideology. Developing national individuals through educating emotions and creating sentimental allegiance to the state is not an activity that Dewey would support. Surely, Dewey would not agree with this interpretation of his ideas, where education served as part of a project that aims at developing a national consciousness about democracy as a form of government rather than a way of life. Yet, Kemalism, since it was heavily influenced by Gökalp's Turkism, did not use Dewey's report for developing a democratic pluralistic society. His recommendations served the ideology of the Gökalpian-Kemalist democratic nation-state that targeted uniformity of the whole rather than the unity of all. Within this context, therefore, Gökalp and Dewey both had an influence on the ideals of the Kemalist Republic. While the latter provided insights into creating a modern western education system, the prior ensured the preservation and improvement of the national characteristics of Turkish culture as a whole body. In other words, Gökalp provided ideas and Dewey helped establish practical ways and means for developing a nation-state through a national education that aims to inculcate national sentiments in students. To conclude, uniformity emerged victorious over unity in the history of Turkish education.

\section{BiBLIOGRAPHY}

Ahmad, Feroz. From Empire to Republic: Essays on the Late Ottoman Empire and Modern Turkey. Istanbul: Istanbul Bilgi University Press, 2008.

- - - "The Late Ottoman Empire." In The Politics of Modern Turkey: Critical Issues in Modern Politics, vol. 3, edited by Ali Çakıroğlu and William Hale, 3-30. New York: Routledge, 2008.

- - - The Making of Modern Turkey. New York: Routledge, 1993.

Akinoglu, Orhan. "Primary Education Curriculum Reforms in Turkey." World Applied Science Journal 3, no. 2 (2008): 195-99.

Akşin, Sina. Essays in Ottoman-Turkish Political History. Istanbul: The Isis Press, 2000.

- _- "Some Observations about the Influence of the French Revolution on the Ottoman Empire." Presentation at the Colloquium on the French Revolution and the Ottoman Empire, Strasbourg, November 16-18, 1989. 
Akural, Sabri M. "Ziya Gökalp: The Influence of His Thought on Kemalist Reforms" Doctoral thesis, Indiana University Bloomington, 1979.

Akyüz, Yahya. Türk Eğitim Tarihi: MÖ 1000-M.S. 2009. Ankara: Pegem Akademi, 2009. Ata, Bahri. "The Influence of an American Educator (John Dewey) on the Turkish Educational System.” The Turkish Year Book 31, no. 2 (2000): 119-30. http:// dergiler.ankara.edu.tr/dergiler/44/671/8547.pdf

Başgöz, İlhan. Turkiye Cumhuriyetinde Egitim ve Atatürk. Ankara: Dost Yayinlari, 1968. -_- Educational Problems in Turkey 1920-1940. Bloomington: Indiana University, 1968.

Bilgi, Sabiha, and Seçkin Özsoy. "John Dewey’s Traveling into the Project of Turkish Modernity." Inventing Modern Self and John Dewey: Modernities and the Traveling of Pragmatism in Education, edited by Thomas S. Popkewitz, 153-77. New York: Palgrave Macmillan, 2005.

Binbaşığlu, Cavit. Türkiye’de Eğitim Bilimleri Tarihi. Istanbul: MEB, 1995.

Brickman, William W. John Dewey's Impression of Soviet Russia and the Revolutionary World Mexico-China-Turkey 1929. Bureau of Publications, Teachers College, Columbia University, 1964.

Çayır, Kenan and İpek Gürkaynak. "The State of Citizenship Education in

Turkey: Past and Present." Journal of Social science Education 6, no. 2 (2008): 50-58.

Dewey, John. A Common Faith. New Haven, CT: Yale University Press, 1934.

-_- Democracy and Education. Middlesex: Echo Library, 2007.

- _ . "Report and Recommendation upon Turkish Education." In The Middle Works of John Dewey, 1899-1924, Volume 15: 1923-1924, Essays, edited by Jo Ann Boydston. Carbondale, IL: Southern Illinois University, 2006.

Dorn, Charles and Doris A. Santoro. "Political Goals and Social Ideals: Dewey, Democracy, and the Emergence of the Turkish Republic," Education and Culture 27, no. 2 (2011): 3-27.

Duru, Kâzım N. Ziya Gökalp. Istanbul: Milli Egitim Basimevi, 1949.

Gökalp, Ziya. Turkculugun Esaslari. Istanbul: Varlik Yayinevi, 1966.

- - - The Principles of Turkism. Translated by Robert Devereux. Leiden: E. J. Brill, 1968.

——_. "Kurt Asiretleri Hakkinda Sosyolojik Tetkikler." Butun Eserleri-Bir: Kitaplar 1, edited by Sevket Beysanoglu, 559-635. Istanbul: YKY, 2007.

Inalcik, Halil. “The Policy of Mehmed II toward the Greek Population of Istanbul and the Byzantine Buildings of the City." Dumbarton Oaks Papers 23/24 (1969/1970): 229-249.

İrem, Nazım. "Turkish Conservative Modernism: Birth of a Nationalist Quest for Cultural Reneval." International Journal of Middle East Studies 34, no. 1 (2002): 87-112.

Karpat, Kemal H. “The Transformation of the Ottoman State, 1789-1908." International Journal of Middle East Studies 3, no. 3 (1972): 243-81. 


\section{Rașit ÇELIK}

Kazamias, Andreas M. Education and the Quest for Modernity in Turkey. London: George Allen \& Unwin Ltd, 1966.

Kili, Suna. The Ataturk Revolution: A Paradigm of Modernization. Istanbul: Turkiye Is Bankasi Kultur Yayinlari, 2003.

Kirby, Fay. Turkiye'de Koy Enstituleri: Colombia Universitesinde Yapilmis Doktora Tezi. Ankara: Ruzgarli Matbaa, 1962.

Landau, Jacob M. Pan-Turkism: From Irredentism to Cooperation. Bloomington: Indiana University Press, 1995.

Noddings, Nel. Philosophy of Education. Boulder, CO: Westview Press, 2007.

Özsoy, Seckin. “'Turkish Modernization,” Democracy, and Education: An Analysis from Dewey's Perspective." Educational Sciences: Theory and Practice 9, no. 4 (2009): 1925-31.

Tarman, Bülent. "Development of Social Studies Curriculum in Turkey and John Dewey's Effect on the Modernization of Turkish Education." International Journal of Progressive Education 7, no. 1 (2011): 45-61.

Turan, Selahattin. "John Dewey's Report of 1924 and His Recommendations on the Turkish Educational System Revisited." History of Education 29, no. 6 (2000): 543-55. Uygun, Selçuk. "The Impact of John Dewey on the Teacher Education System in Turkey." Asia-Pacific Journal of Teacher Education 36, no. 4 (2008): 291-307.

Walzer, Michael. On Toleration. New Haven, CT: Yale University Press, 1997.

Wilson, Lucy L. W. "Education in the Republic of Turkey." School and Society 28, no. 725 (1928): 602-10.

Yilmaz, Kaya. "Democracy through Learner-Centered Education: A Turkish Perspective." International Review of Education 55 (2009): 21-37.

\section{Notes}

1. Mustafa Kemal Atatürk (1881-1938) is the founder and the first president of the Turkish Republic.

2. For detailed discussion, see Kemal H. Karpat, "The Transformation of the Ottoman State, 1789-1908," International Journal of Middle East Studies 3, no. 3 (1972): 243-281.

3. Feroz Ahmad, The Making of Modern Turkey (New York: Routledge, 1993), 15.

4. This refers to the ideology developed by Atatürk, which sets core principles and outlines the basic characteristics of the Turkish Republic.

5. Michael Walzer, On Toleration (New Haven: Yale University Press, 1997). Will Kymlicka and Magda Opalsk, eds., Can Liberal Pluralism be Exported?: Western Political Theory and Ethnic Relations in Eastern Europe (New York: Oxford University Press, 2001), 137.

6. Mehmed II is known as the Conqueror of Constantinople. See Feroz Ahmad, "The Late Ottoman Empire," in The Politics of Modern Turkey: Critical Issues in Modern Politics, vol. 3, eds. Ali Çakıroğlu and William Hale (New York: Routledge, 2008), 19-20; Halil Inalcik, The Policy of Mehmed II. Halil Inalcik, "The Policy of Mehmed II toward the Greek Population of Istanbul and the Byzantine Buildings of the City," Dumbarton Oaks Papers 23/24 (1969-1970): 229-249. 
7. For a detailed discussion, see Sina Akşin, "Some Observations about the Influence of the French Revolution on the Ottoman Empire" (presentation, Colloquium on the French Revolution and the Ottoman Empire, Strasbourg, November, 16-18, 1989). Also, available in Sina Akşin, Essays in Ottoman-Turkish Political History (Istanbul: The Isis Press, 2000), 117-125.

8. Feroz Ahmad, From Empire to Republic: Essays on the Late Ottoman Empire and Modern Turkey (Istanbul: Istanbul Bilgi University Press, 2008), 175-177.

9. Jacob M. Landau, Pan-Turkism: From Irredentism to Cooperation (Bloomington: Indiana University Press, 1995), 74.

10. Suna Kili, The Atatürk Revolution: A Paradigm of Modernization (Istanbul: Turkiye Is Bankasi Kultur Yayinlari, 2003), 207.

11. Sabri M. Akural, "Ziya Gökalp: The Influence of His Thought on Kemalist Reforms" (Ph.D. dissertation, Indiana University Bloomington, 1979), 332, 367.

12. Gökalp systematically analyzed Pan-Turkism and is considered as the "Grand Master of Pan-Turkism," see Landau, Pan-Turkism, 36-37. He is also known as "the foremost theoretician of Turkish nationalism during the Second Constitutional Period." See Kili, The Atatürk Revolution, 207.

13. Akural, Ziya Gökalp, 322.

14. RPP is the first political party of the Republic of Turkey and was founded by Atatürk. RPP was the single political organization that led the entire political activity of the Turkish Republic in the single-party period until 1945.

15. Akural, Ziya Gökalp, 324.

16. Ibid., 320-321.

17. This is an alternative name for Kemalism.

18. Kili, The Atatürk Revolution, 199.

19. Ibid.

20. Akural, Ziya Gökalp, 355.

21. Kili, The Atatürk Revolution, 215.

22. Kâzım Duru, Ziya GökalpGökalp (Istanbul: Milli Egitim Basimevi, 1949), 151.

23. Akural, Ziya Gökalp, 332.

24. Ziya Gökalp, The Principles of Turkism, trans. Robert Devereux (Leiden: E. J. Brill, 1968), 16. In Turkish, see Ziya Gökalp, Turkculugun Esaslari [The Principles of Turkism] (Istanbul: Varlik Yayinevi, 1966).

25. Akural, Ziya Gökalp, 357.

26. Ibid.

27. Ziya Gökalp, "Kurt Asiretleri Hakkinda Sosyolojik Tetkikler," Butun Eserleri-Bir: Kitaplar 1, ed. Sevket Beysanoglu (Istanbul: YKY, 2007), 559.

28. Kili, The Atatürk Revolution, 208.

29. Charles Dorn and Doris A. Santoro, "Political Goals and Social Ideals: Dewey, Democracy, and the Emergence of the Turkish Republic," Education and Culture 27, no. 2 (2011): 3-27.

30. Gökalp, The Principles, 12-16.

31. Ibid., 15.

32. Ibid., 16 .

33. Ibid.

34. Ibid., 19.

35. John Dewey, A Common Faith (New Haven: Yale University Press, 1934), 43. 


\section{Rașit ÇELIK}

36. Ibid., 44.

37. Ibid., 48,51 .

38. Ibid., 33, 36, 39 .

39. John Dewey, Democracy and Education (Middlesex: Echo Library, 2007), 65.

40. Ibid., 67.

41. See Dewey, A Common Faith, 77.

42. See Chapter 9 in Dewey, Democracy and Education.

43. Ibid., 68 .

44. See, Ibid., 78.

45. For detailed information about the appearance of Dewey's ideas in Turky, see Bahri Ata, "The Influence of an American Educator (John Dewey) on Turkish Educational System," The Turkish Yearbook 31, no. 2 (2000): 121-123.

46. Ibid., 122.

47. Lucy L. W. Wilson, "Education in the Republic of Turkey," School and Society 28, no. 725 (1928): 602

48. John Dewey, "Report and Recommendation upon Turkish Education," The Middle Works of John Dewey, 1899-1924, Volume 15: 1923-1924, Essays (Electronic Edition: http:// www.library.nlx.com/xtf/view?docId=dewey_ii/dewey_ii.20.xml;chunk.id=div.mw.15.57;toc .depth=1;toc.id=div.mw.15.57;brand=default\#), 274-299.

49. Ibid., 275.

50. Dewey, "Report and Recommendation," 275.

51. Ibid.

52. Seçkin Özsoy, ““'Turkish Modernization,” Democracy, and Education: An Analysis from Dewey's Perspective," Educational Sciences: Theory and Practice 9, no. 4 (2009): 1927.

53. See Bülent Tarman, "Development of Social Studies Curriculum in Turkey and John Dewey's Effect on the Modernization of Turkish Education," International Journal of Progressive Education 7, no. 1 (2011): 45-61; Selçuk Uygun, "The Impact of John Dewey on the Teacher Education System in Turkey," Asia-Pacific Journal of Teacher Education 36, no. 4 (2008): 291-307.

54. See Kenan Çayır and İpek Gürkaynak, "The State of Citizenship Education in Turkey: Past and Present," Journal of Social Science Education 6, no. 2 (2008): 50-58; Nazım İrem, “Turkish Conservative Modernism: Birth of a Nationalist Quest for Cultural Renewal," International Journal of Middle East Studies 34, no. 1 (2002): 87-112; Orhan Akinoglu, "Primary Education Curriculum Reforms in Turkey," Word Applied Science Journal 3, no. 2 (2008): 195-199.

55. See Tarman, "Social Studies Curriculum," 45-61.

56. See Akinoglu, "Primary Education," 197; Tarman, "Social Studies Curriculum," 45-61.

57. Dewey, before his visit to Turkey, had an opportunity to observe Chinese education and culture. He made significant contributions to the development of education in China. Also, he continued visiting different countries for educational purposes after his journey to Turkey. For example, he visited China in 1919-1921, Turkey in 1924, Mexico in 1926 and 1937, and Russia in 1928. For detailed information, see William W. Brickman, John Dewey's Impression of Soviet Russia and the Revolutionary World Mexico - China - Turkey 1929 (Bureau of Publications, Teachers College, Columbia University, 1964), 1-168.

58. Dewey, "Report and Recommendation," 280.

59. Ibid.

60. İlhan Başgöz, Educational Problems in Turkey 1920-1940 (Bloomington: Indiana University, 1968), 63-67; Fay Kirby, Turkiye'de Koy Enstituleri: Colombia Universitesinde Yapilmis Doktora Tezi (Ankara: Ruzgarli Matbaa, 1962), 33-37. 
61. Dewey, "Report and Recommendation," 281.

62. Andreas M. Kazamias, Education and the Quest for Modernity in Turkey (London: George Allen \& Unwin Ltd, 1966), 141.

63. Uygun, “The Impact," 291-307.

64. Ibid., 291.

65. See Kaya Yilmaz, "Democracy through Learner-Centered Education: A Turkish Perspective," International Review of Education 55 (2009): 21-37; Selahattin Turan, “John Dewey's Report of 1924 and His Recommendations on the Turkish Educational System Revisited," History of Education 29, no. 6 (2000): 543-555; Uygun, “The Impact," 291-307.

66. Sabiha Bilgi and Seçkin Özsoy, "John Dewey's Traveling into the Project of Turkish Modernity." Inventing Modern Self and John Dewey: Modernities and the Traveling of Pragmatism in Education, ed. Thomas S. Popkewitz (New York: Palgrave Macmillan, 2005), 164-165.

67. Ibid. 166; Akyüz, Türk Eğitim Tarihi, 405.

68. See Uygun, “The Impact," 291-307.

69. Bilgi and Özsoy, "John Dewey's Traveling", 171. For more information about the Village Institutions, see Akyüz, Türk Eğitim Tarihi, 392-397; Cavit Binbaşığlu, Türkiye’de Eğitim Bilimleri Tarihi (Istanbul: MEB, 1995), 18-19; For detailed information, see Kirby, Turkiye'de Koy Enstituleri, 199-299.

70. See Dewey, "Report and Recommendation," 276.

71. Bilgi and Özsoy, "John Dewey's Traveling," 157, emphasis added.

72. Nel Noddings, Philosophy of Education (Boulder: Westview Press, 2007), 36.

73. Dewey, Democracy and Education, 68.

Raşit Çelik is at Karadeniz Technical University.

E-mail: rcelik@umail.iu.edu 
